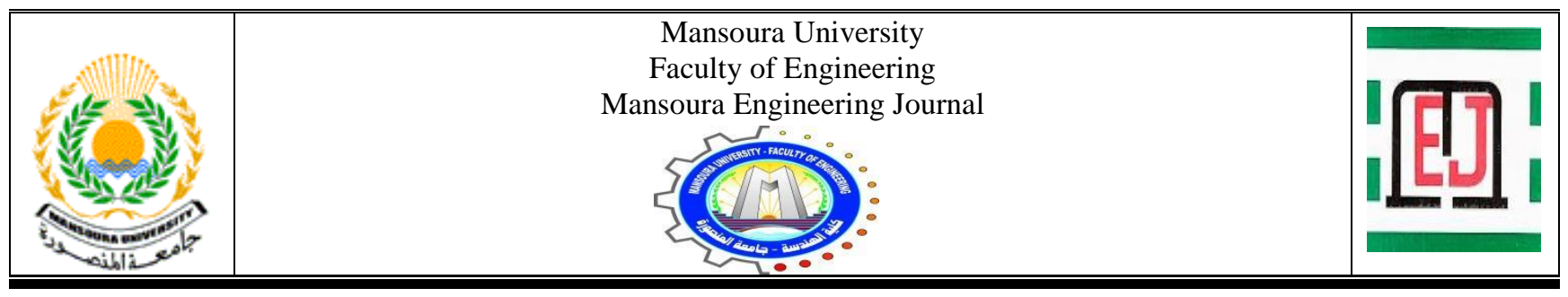

\title{
Zero Carbon Architecture in the Future Scenarios Case Study (Industrial Building at New Damietta City, Egypt)
}

Madiha Hamed Abd Elsattar Amasha, Mohamed Salah El Din EL sayed, Alaa Mohamed El Eishy and Ahmad El Tantawy Awad

\begin{tabular}{|l|}
\hline KEYWORDS: \\
Global warming \\
Zero carbon Architecture \\
Carbon emissions \\
\\
\end{tabular}

Abstract: Global warming is one of the most public issues that occupy the minds of everyone, as modern societies suffer from total depends on energy, which causes increased carbon emissions and greenhouse gases, which cause global warming.

The issue of research is therefore to reduce carbon emissions in the building sector using the principles of zero-carbon architecture (ZCA) which produces at least as much energy as it uses in a year, which means obtaining green architecture using modern technologies and use alternative energy to reduce energy consumption.

The research aims to approach and measure Zero Carbon Architecture in Egypt (ZCAE), then clarification the returns of applying ZCA for the state and scenarios of ZCA application in Egypt, New Damietta city by using smart material \& pv A photovoltaic system to reduce the consumption of energy uses to obtaining ZCA and this confirmed by a questionnaire for specialists, which was placed as an appendix ,then Using an analytical method to explore and learn from some of the examples applied to $\mathrm{ZCA}$ in the world, and to obtain results and principles that have been applied in the applied research as a case study.

The results of the research were to obtain a modified model applied ZCA for an industrial building and to maximize the results by applying it to the industrial zone, as well as making a measurement for ZCA using zero tool application.
Received: (06 October, 2020) - Revised: (30 January, 2021) - Accepted: (16 February, 2021)

Corresponding Author: Madiha Hamed Amasha, Assistant Professor at Architecture Engineering Department, University of Mansoura, Egypt, (email: madihahamed@mans.edu.eg).

Mohamed Salah El Sayed, Professor at Architecture Engineering Department, University of Mansoura, Egypt, (e-mail: drsalah22222@hotmail).

Alaa El Eishy, Associate Professor at Architecture Engineering Department, University of Mansoura, Egypt, (e-mail: arabeskal_arch@yahoo.com).

Ahmad El Tantawy, Assistant Professor at Architecture Engineering Department, University of Mansoura, Egypt, (e-mail: eltantawy_a@yahoo.com).

\section{INTRODUCTION}

$\mathrm{G}$ REEN buildings are primarily the concept of how to conserve energy usage in the building and minimize carbon dioxide emissions, as well as ZCA depending on the boundary and the metric, various meanings may be acceptable, depending on the project objectives and the values of the design team and building owner. Zero carbon architecture may be defined in many ways, such as [1]: 
- Net Zero Site Energy: A site ZEB (zero energy building) produces at least as much energy as it uses in a year when accounted for at the site.

- Net Zero Source Energy: A source ZEB (zero energy building) produces at least as much energy as it uses in a year when accounted for at the source. Source energy refers to the primary energy used to generate and deliver energy to the site. To calculate a building's total source energy, imported and exported energy is multiplied by the appropriate site-to-source conversion multipliers.

- Net Zero Energy Costs: In a cost ZEB (zero energy building), the amount of money the utility pays the building owner for the energy the building exports to the grid is at least equal to the amount the owner pays the utility for the energy services and energy used over the year.

- Net Zero Energy Emissions: A net-zero emissions building produces at least as much emissions-free renewable energy as it uses from emissions-producing energy sources.

From this point, the research seeks to examine the effective use technology of zero-carbon architecture to reach the sustainable architecture design according to future scenarios in Egypt to help our earth to combat the pollution and reduce the global warming effect.

To achieve the aim of the study, the research relied on using the theoretical, analytical, and then applied the study method as a tool to prove the validity of the hypotheses.

In the theoretical part, the research mentioned ZCA's advantages and disadvantages, and the difference between ZCA and green architecture and some ZCA technologies.

As for the analytical part, it was an analysis of a contemporary model applied to the principles of ZCA according to the standards that had been developed, and then the applied part was to obtain a modified industrial building that applied to ZCA standards.

\section{ZERO CARBON ARCHITECTURE}

As before mentioned in the introduction the definitions of $\mathrm{ZCA}$, in this part we will mention the advantages and disadvantages of ZCA, this part will also show the difference between ZCA and green architecture they will be listed as follows:

A.Advantages and disadvantages of ZCA [11], [6]

\section{A-1 Advantages of ZCA}

a) Isolation from potential electricity price rises for building owners

b) Greater comfort due to more standardized temperatures in the interior

c) Shortened energy austerity requirements

d) Reduced overall ownership costs due to increased energy efficiency

e) Reduced gross monthly net living costs

f) Improved reliability-25-year warranty for photovoltaic systems-uncommon failure during weather problems

g) Compared to an afterthought retrofit, the additional cost for a new building is reduced compared to the old one.

h) Higher resale value as more ZEBs were needed by potential owners than available supply

i) Compared to similar conventional buildings; the value of a ZEB building should be increased every time energy costs rise.

j) Future legislative constraints and carbon taxes/penalties will need costly upgrades to outdated buildings.

\section{A-2 Disadvantages of ZCA}

a. Initial costs can require greater effort to understand, apply, and qualify for ZEB grants.

b. Very few designers or manufacturers have the skills or expertise to produce ZEBs

c. For utility companies, possible decreases in future renewable energy costs may reduce the value of capital invested in energy efficiency.

d. The price of new photovoltaic solar cell technology equipment has fallen by around 17 percent per year.

e. Recovery of higher initial costs for the resale of buildings

f. While a single house would use a net-zero energy average for one year, rising energy is needed at a time when the grid's peak demand is occurring. Therefore, the ZEB should not reduce the necessary capacity of the power plant.

g. Incarnated power, heating and cooling energy, and resource utilization are greater than adequate without an optimized thermal envelope. By definition, the ZEB does not require a minimum level of heating and cooling efficiency, allowing oversized renewable energy systems to fill the energy gap.

h. The harvesting of solar energy using the house envelope only operates in areas unimpeded from the south. In the south (for the northern hemisphere, or in the north for the southern hemisphere), facing shade or wooded surroundings, solar energy capture would not be optimized.

\section{B. Zero energy building versus green building [10]}

TABLE 1

ADAPTED FROM THE RESEARCHER

Green building fig 1

Use resources more effectively and decrease the negative environmental effects of a building.

To be habitable and meet the needs of inhabitants, they need imported energy and/or fossil fuel.

\section{Zero energy buildings fig 1}

Achieving one main green-building objective of reducing energy usage and greenhouse gas emissions entirely or quite substantially for the life of the building.

"In all respects, zero energy buildings may or may not be considered" green, "such as waste reduction, the use of recycled building materials, etc.

Net-zero buildings tend to have a significantly smaller environmental effect on the life of the construction. 


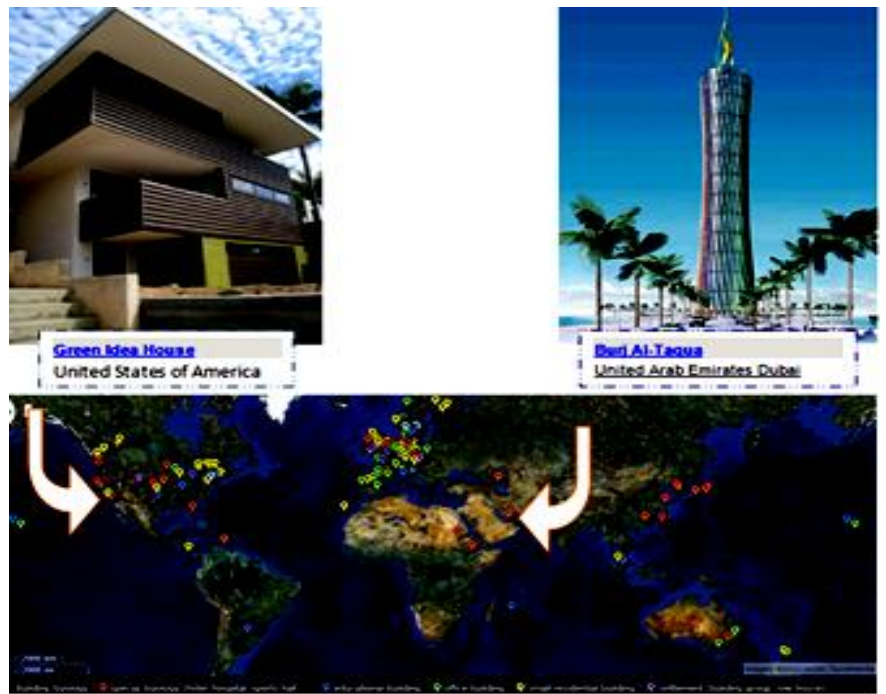

Fig. 1 illustrate Zero energy building versus green building Ref: World Map of 360 international known Net Zero Energy Buildings, http://www.enob.info/en/net-zero-energy-buildings/map/10/20

\section{LOW AND ZERO CARBON TECHNOLOGIES IN SMART BUILDING}

\section{A. Low and zero carbon technologies}

The idea of 'zero carbon homes'; over the course of a year, they must have zero net emissions from all energy usage in the house. The government proposes a three-tiered solution to achieving net-zero pollution, shown as a hierarchical triangle in Fig .2. [5], [9].

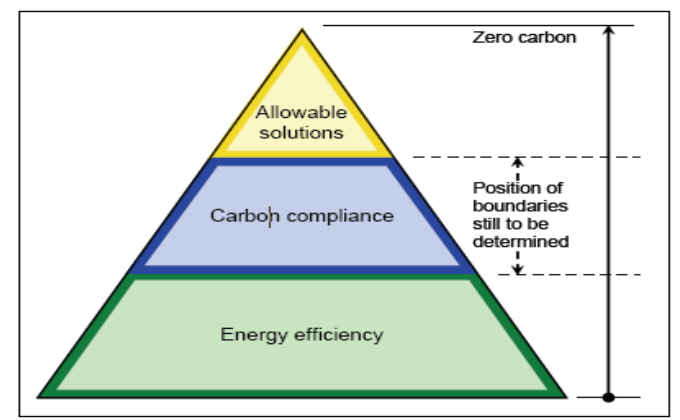

Fig .2 Hierarchy of permissible methods to achieve zero carbon developments

Ref: Hetherington, Robina; Laney, Robin and Peake, Stephen, Zero and low carbon buildings, Springer, 2009. p2.

The objective described by the triangle's bottom tier in Figure ( 2 ) is to create building envelopes with very high energy efficiency requirements, so that little or no energy is needed to heat or cool the building. This involves very high levels of building fabric insulation Thermal transmittance (Uvalues), thermal bridge power, a substantial reduction of air permeability, thermal mass integration, and the use of incidental benefits such as metabolic, lighting, solar ,and appliances. These are supposed to be stable approaches, requiring lower lifecycle costs than other low or zero technologies that comprise the other two stages, likely higher maintenance. The influence of fabric and energy conservation initiatives has limitations. 'Carbon enforcement', the triangle's middle band, covers a range of steps, including generation technologies, such as fabric-integrated solar panels, heat pumps from the ground source, and combined heat and power plants located within or closely linked to growth.

For certain building types, reaching net-zero carbon emissions through energy conservation and on-site 'carbon enforcement' initiatives might not be theoretically feasible. There may be a need to implement (predominantly) off-site steps, or 'allowable solutions', to reach the proposed norm. Local energy systems, payment credits for local energy networks, upgrading of existing local buildings, etc. are the off-site options considered in the consultation, as shown in Figure (3). Other permissible solutions include in-building equipment such as energy-efficient appliances, such as IT equipment for ultra-low energy, or advanced heating/cooling/lighting control systems.

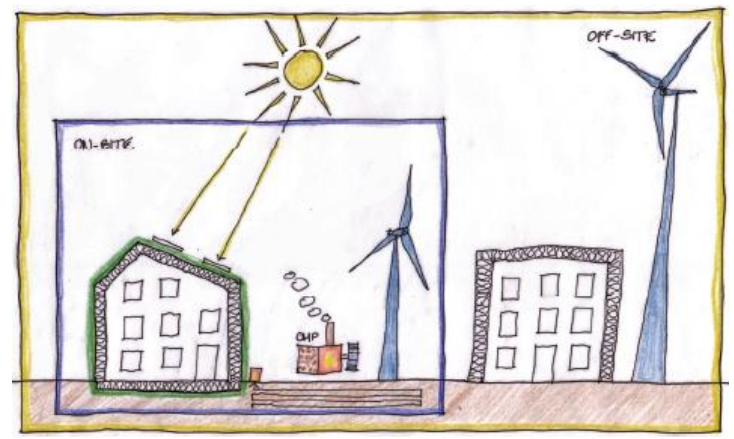

Fig.3. On-site and off-site compliance

Ref:] Hetherington, Robina; Laney, Robin and Peake, Stephen (2010). Zero and low carbon buildings: A driver for change in working practices and the use of computer modelling and visualization. In: 14th International Conference on Information Visualisation, 27-29 July 2010, London South Bank University, London, UK. p2

\section{B. ICT for a Low Carbon Economy Smart Buildings [11]}

In a smart building, many technologies are used, from design and construction materials to façade finishing, to the use of modern technologies in means of communication Information and communications technology (ICT).

So, in the coming years, the reduction in energy consumption using ICT as the primary enabler technology is estimated to be approximately $15 \%$.

The study estimates contributions from various technologies and policies to that reduction figure, emphasizing that ICT instruments for enhancing energy efficiency in buildings at the design stage and smart building management systems could have the greatest impact. The research \& development aimed at networks in future smart buildings should be built for this reason around the following fundamental pillars [4]:

a) The "intelligent" objects are an intelligent physical entity simply means that it is active, digital, interconnected, can function in a certain way autonomously, can be reconfigured and regulates local resources such as electricity, storage of data, etc. [9]. 
b) The communications i.e. "connect the building to various networks of internet, electricity, etc."

c) The "smart BMS" The battery management system for monitoring and control of Lithium-Ion energy storage systems to store the electric energy produced from solar panels and use them later.

d) The multimodal interactive interfaces, that multimodal interaction makes communication freer and more normal, interacting with both input and output automated systems [10].

e) Wired and wireless sensors to track smart building system environmental data in real-time and the combination of automated and manual household control platform can be accomplished [2].

f) Proprietary platforms \& networks is a network with a platform, users rely on a shared platform, supported by one or more intermediaries, which includes infrastructure and user rules [3].

g) Multimodal context-aware interfaces/devices to enhance communications.

h) Actual impact in terms of energy savings where Smart buildings save energy compared to other buildings.

i) Level of interoperability which is three: fundamental, systemic, and semantic. Basic interoperability is one IT system's ability to send information to another IT system.

j) User-friendliness for all users.

k) Economic efficiency for the building as a whole and as a return to the user and the state.

\section{CONTEMPORARY PARADIGM OF ZCA}

This part will represent the analytical part which is an applied construct analysis of contemporary paradigms of zerocarbon building, selected upon its energy efficiency, renewable energy $\{\mathrm{pv}\}$ system, awards which had got and building use, after clarifying the criteria for applying ZCA principles in buildings

A-the key components of the zero carbon building standard [14]:

The ZCA application criteria in the building "THE KEY COMPONENTS OF THE ZERO CARBON BUILDING STANDARD":

i. ZERO CARBON BALANCE No net greenhouse gas (GHG) emissions are related to the construction operations. GHG emissions are offset by generating clean, on-site, or off-site renewable energy.

ii. EFFICIENCY New construction designs consider peak energy while optimizing energy efficiency with an emphasis on the building envelope and ventilation techniques that drive down thermal demand.

iii. Renewable energy on-site is integrated into new construction projects to provide added sustainability, reduce environmental impacts off-site, and plan buildings for the future of distributed energy.

\section{B-Example of successful zero carbon buildings: Table (2)}

Although rare, there are contemporary examples of industrial buildings applying principles of ZCA

In this building, carbon emissions were reduced by relying on the production of solar energy from photovoltaic panels that were placed above the parking to obtain the energy needed to operate the plant and obtain clean energy as a breakthrough for this field in industrial buildings in particular and the provision of 360 tons of carbon dioxide per year as will be shown in the table below:

TABLE (2)

ADAPTED FROM THE RESEARCHER ABB'S FIRST CARBON NEUTRAL FACTORY IN LUDENSCHEID, GERMANY [18]

\begin{tabular}{|c|c|}
\hline Author(s): & $\begin{array}{l}\text { A. ABB Group in Zurich, } \\
\text { Switzerland }\end{array}$ \\
\hline Illustration: & Fig (4) ABB's factory in Germany [18] \\
\hline Project aim: & $\begin{array}{l}\text {-this project aims } \\
\text { to save } 630 \text { tones of } \mathrm{CO} 2 \text { per annum } \\
\text { - to be the first carbon-neutral industrial } \\
\text { building }\end{array}$ \\
\hline Building address: & in Ludenscheid, Germany \\
\hline Building type: & Industrial building \\
\hline Building size: & More than 7,300 square meters \\
\hline $\begin{array}{l}\text { Building envelope } \\
\text { construction: }\end{array}$ & $\begin{array}{l}\text { - The structure from steel and concrete } \\
\text { - brick walls and the ceiling made of } \\
\text { reinforced concrete } \\
\text {-The parking be covered by PV solar } \\
\text { system }\end{array}$ \\
\hline $\begin{array}{l}\text { Building } \\
\text { systems: }\end{array}$ & $\begin{array}{l}\text { - The flexible energy management } \\
\text { system OPTIMAX ® from ABB } \\
\text { Ability TM Energy Management for } \\
\text { Sites is the technical centerpiece of the } \\
\text { entire Ludenscheid system. } \\
\text {-The digital solution enables } \\
\text { continuous monitoring, and efficient } \\
\text { monitoring of energy output, use and } \\
\text { storage. Based on predictive data, this } \\
\text { learning system determines the optimal } \\
\text { energy flow and offset deviations in } \\
\text { real-time. } \\
\text { - In Ludenscheid, ABB has not only } \\
\text { installed a new photovoltaic and power } \\
\text { management system but also has } \\
\text { implemented other ABB technologies, } \\
\text { such as a } 200 \mathrm{~kW} \text { battery power storage }\end{array}$ \\
\hline
\end{tabular}




\begin{tabular}{|c|c|}
\hline & $\begin{array}{l}\text { (BESS) with a capacity of } 275 \mathrm{kWh} \\
\text { and ABB charging points, where } \\
\text { personnel and visitors can free charge } \\
\text { their electric cars which adds to the } \\
\text { regional green balance of the plant. } \\
\text { - A smart power delivery switch is used } \\
\text { to complete this one-source energy } \\
\text { management solution. }\end{array}$ \\
\hline $\begin{array}{l}\text { Included } \\
\text { renewable energy } \\
\text { technologies: }\end{array}$ & $\begin{array}{l}\text { - The Ludenscheid plant is powered by } \\
\text { a set of solar panels covering approx } \\
\text { photovoltaics. On roofs that cover the } \\
\text { on-site parking lot, } 7,300 \text { square meters } \\
\text { and - to save space - are installed. } \\
\text {-The Ludenscheid plant can together } \\
\text { produce about } 14 \% \text { more energy on- } \\
\text { site than it requires. Any surplus } \\
\text { electricity is fed into the public grid } \\
\text { that contributes to the region's } \\
\text { sustainable energy supply. }\end{array}$ \\
\hline Final energy use: & $\begin{array}{l}\text { PV system is expected to supply } \\
\text { approx. } 1,100 \mathrm{MWh} \text { of climate-neutral } \\
\text { solar power a year, equivalent to } 340 \\
\text { private households' annual demand. }\end{array}$ \\
\hline $\begin{array}{l}\text { Improvement } \\
\text { compared } \\
\text { national } \\
\text { requirements: }\end{array}$ & $\begin{array}{l}\text { ABB technology is installed and can } \\
\text { produce ample power to operate the } \\
\text { entire factory and even feed the grid } \\
\text { electricity. If on-site solutions cannot } \\
\text { meet the high electricity demand, MVV } \\
\text { Energy AG is responsible for supplying } \\
\text { additional green energy, which ensures } \\
\text { a } 100 \text { percent CO2 neutral production. }\end{array}$ \\
\hline $\begin{array}{l}\text { Experiences/ } \\
\text { lessons learned: }\end{array}$ & $\begin{array}{l}\text {-reducing carbon emission } \\
\text {-Getting electricity from the sun. } \\
\text { - ABB provides goods and services that } \\
\text { play a decisive role in enhancing } \\
\text { business sustainability. More than half } \\
\text { of ABB's global revenues come from } \\
\text { technologies that tackle climate change } \\
\text { causes. }\end{array}$ \\
\hline
\end{tabular}

Therefore, research calls for application to factories as a case study at the outset to reduce the proportion of carbon emissions in the implementation of the Paris Agreement, as the factories are at the top.

Therefore, there is a research gap as a case study for applying the principles of ZCA to an industrial building and taking this into account in the applied part of the research.

So the research reached some conclusions or criteria that will be used in the case study in the applied part of the research as follows:

- The outcome of the theoretical and analytic study in the previous parts, which recommends the beginning of the application of ZCA in industrial buildings for a research gap mentioned before.

- Application is recommended to start with buildings that consume more energy than others as the industrial ones, benefit from energy-saving economically, environmentally and urbanely, but the question still arises Will the application first on a short-term or long-term factories, another question Will the work of the study of traditional feasibility or sustainable feasibility study?

- We can decrease the carbon consumption in the building sector especially industrial building.

- We can Measure and make a certification for ZCA in Egypt such as LEED.

\section{How to Apply \& Measure Zero Carbon ARCHITECTURE IN EGYPT (ZCAE) IN INDUSTRIAL SECTOR A CaSe Study}

To apply the principles of ZCA, it is necessary to apply the criteria and mechanisms that were extracted from the theoretical part, which are summarized in:

First, reduce the building's greenhouse gas emissions

Secondly, enhancing energy efficiency, especially in designing the building envelope, starting with the materials used and their role in energy conservation to insulation and so on.

Third, the use of alternative renewable energies, such as the use of solar energy.

Therefor the applied part was linked to the theoretical part, as it is an application to reduce carbon emissions and a solution to the problem of global warming. It has also been applied to industrial buildings because there is a research gap for applying ZCA to industrial buildings due to its large energy consumption and thus it has the largest share of carbon emissions, so this idea was adopted to make a scenario to modify an existing industrial building and convert it to a building that applies the principles of ZCA through the application to ZREOTOOL, which adopts strategies for the application of ZCA principles in America and the work of the 2030 and 2050 plan to achieve zero carbon. During an application to calculate solar energy, starting from choosing the type of solar panels to calculating angles and distances according to the location of the building, and Nasr Energy Company's calculations were approved.

So Non-renewable energy sources (ZCA) are being replaced by reducing energy use and generating adequate removable sources to meet their buildings' Annual Energy Needs. Although the idea of ZCA in the construction industry is widely known, there is no universal definition. In order to try to promote such buildings, and implement traditional design techniques, this poses a challenge [13].

The study will be maximizing the benefits of ZCA implementation by applying it to the industrial zone depend on the result as a whole to provide economic, environmental and urban benefits to the state as will be seen.

\section{A. Zero carbon architecture in Egypt (ZCAE):}

As previously stated in the theoretical section of the study, the word "zero" applies to houses, which are either zero energy or zero emissions, representing an annual energy efficiency balance with renewable energy services. Researchers estimate hundreds of zero commercial buildings and thousands of zero homes around the world today [12] 
A: 100 MADIHA HAMED ABD ELSATTAR AMASHA, MOHAMED SALAH EL DIN EL SAYED, ALAA MOHAMED EL EISHY AND AHMAD EL TANTAWY AWAD

The key aspect considered at the ZCA is the climate with all its branches; this makes it different from other tools for energy efficiency.

So, in common figure (5), ZCA buildings appear to have a certain set of features and technologies [7]

ZNE buildings tend to have a

certain suite of features and

technologies in common

(1) Lighting: Daylighting as the primary source of illumination, plus LED lighting and vacancy controls

(2) HVAC: variable capacity heat pumps, ground source heat pumps, and radiant systerns; technologies such as packaged roof top units are almost totally absent

(3) Ventilation: Variable flow fans, advanced controls like demand control ventilation, and energy recovery ventilation

(4) Envelope: High insulation levels, highperformance windows, and conscious efforts to reduce thermal bridging and infiltration

(5) Plug load: Attention to plug load equipment like high-efficiency appliances and computers, and plug load controls

Fig .5 ZCA certain suite of features and technologies

Ref/ New building institute, Five Steps to Net Zero Energy, 2016 National Grid USA Service Company, p5

Although the Egyptian national energy strategy has no reference to Zero-carbon architecture, no literature provides any data about existing ZCA in Egypt, and only a small number of researches tackle the subject, so the ZCA solution seems to fit perfectly.

So ZCAE can use these steps above to apply principles of Zero Carbon Architecture in Egypt Especially since it suits the current and future waves of new cities in the map of urban (Urban Development Plan) trends in Egypt to obtain a life that may seem more developed and in line with the technological development that the world is now witnessing; maybe this is what the fourth-generation cities that the Egyptian state is now implementing are achieving.

\section{B. ZCAE General Methodology}

There are some guidelines or design strategies to act as a clear methodology for design and measure ZCAE in general and special in industrial buildings at first in new cities:

- Consider inclusiveness and flexibility.

- Avoid complexity.

- Good knowledge about the existing situation with reformulates reality in the future.

- Design \& Retrofitting the building in a futuristic way that simulates reality.

- Creating an innovative targeted scenario with a reference vision based on a sustainable feasibility study.

- The scenario should be holistic by considering all the following aspects; the economic, environmental, and aesthetic aspects with documenting the environmental performance of the building.

- This scenario is the researcher's diligence based on some previous models and the use of carbon-free architecture strategies for zero tool programs and strategies in America that can be applied according to the climate in any region of the world.

So, there are three basic steps to be followed to obtain a model for ZCAE industrial buildings that will apply to the industrial zone in new cities:

\section{Data Collection and Analysis:}

The first step toward ZCAE is to collect and analyze local climate data and the energy system design in the house.

\section{Energy Performance Enhancement:}

The second stage will concentrate on improving the building's energy efficiency and evaluating the effects using the Zero Tool application software techniques.

\section{Renewable Energy Systems:}

Different programming may be used for simulating the power demand and generation, the exact number of PV arrays in addition to the scheme of linking the renewable energy to the grid should be calculated based upon climate analytical knowledge and software techniques.

\section{Methodology of the scenario:}

- -The scenario of retrofitting the existing building will start with the specification of the field of the study and choosing the type of building to be used in the study according to the results.

- -The energy consumption data for the building and environmental data indoors and outdoors such as air temperature, air moisture, $\mathrm{CO} 2$, luminance, the noise level will be gathered after the description of the building type because these factors directly affect thermal comfort as well as the environmental qualities of air inside the structural complex.

- -Then these data will be analyzed to find out the building's desired energy performance according to the ZCAE general methodology.

\section{Retrofit the building (case study) to suit ZCAE:}

To obtain a ZCAE building (case study) apply the ZCA principles mentioned before in the research that to have a certain set of features and technologies that concentrated on the building's envelope and then we choose a power generation system that fits the building energy consumption.

\section{E. Retrofit the building's envelope:}

As shown in fig (6) 3D modeling for the case study, the building's envelope contains several elements to become a ZCA building as:

a) Using high-performance windows with high-level insulation.

b) Using walls with a thickness of $25 \mathrm{~cm}$ with a high insulation level.

c) Providing daylighting, as well as natural ventilation plus artificial ventilation. 
d) Using high-grade insulation materials for roofs.

e) Use Nanomaterials to reduce maintenance and save energy.

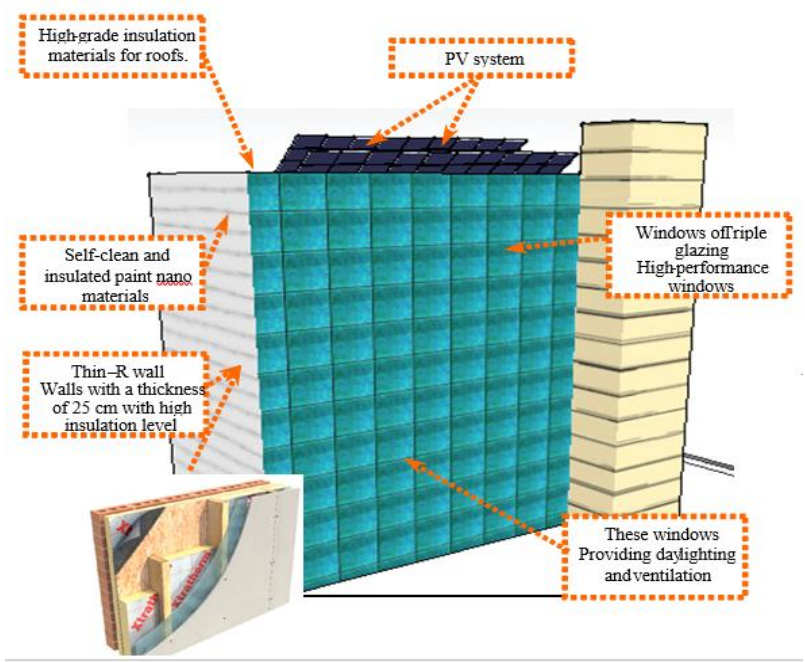

Fig .6 3D modeling for case study by researcher

\section{F. Measuring ZCAE by Zero Tool:}

Paul Torcellini, Ph.D., P.E. at the National Renewable Energy Laboratory in Golden, Cologne, said, " green buildings, sustainable buildings, and buildings with high efficiency but success is difficult to quantify." "ZCA gives you an energy target that you can foresee and calculate, and you know if you've accomplished - 'No."'[13]

So, the study will depend on the Zero tool scale to measure ZCAE evaluate the industrial building and its environmental performance, then proposing and applying this tool as a certificate for ZCAE in Egypt.

Zero Tool like LEED as acerteficate for ZCAE.

Zero tool [19] is an application developed by Architecture 2030 for building sector professionals.

In Zero Tool there is A Zero Score which is a value assigned to a building, intended to help project teams understand the building's energy performance and progress towards achieving Zero Net Carbon. A Zero Score is a relative performance metric, so it can be used to compare buildings across all locations, types, and sizes.

When entering the case study data (the industrial building), in ZERO TOOL the results were as follows fig (7):

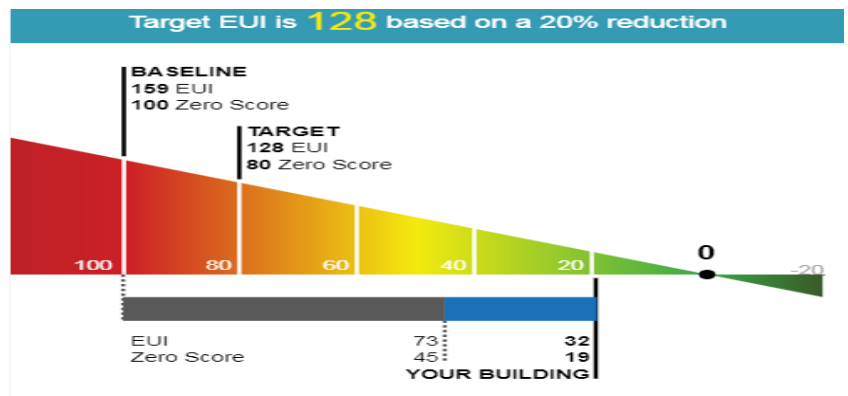

Fig .7 Results on the ZERO SCORE with the $20 \%$ reduction target Ref: zero tool organization. (2019) from zerotool.org, https://zerotool.org/about/\#toggle-id-6, 8/2019

\section{G. using Renewable Energy Technology design (solar photo- voltaic panels)}

By using the data gathered in the previous section, some analysis will be done to determine the best PV panel inclination angle and the best type that would suit the Egyptian context.

In the following section, the exact design and implementation steps will be discussed as applying from Naser solar website [16].

This site allows entering the building data in terms of the coordinates, and the capacity of the solar panels in kilowatts, so it gives calculations of the potential solar radiation of the site, the number of solar panels and the distances between them and the appropriate angles to place them throughout the year.

a. site basic data:

Location: New Damietta, Egypt

Average Solar radiation rate annually: $3084 \mathrm{KWh} / \mathrm{m} 2$

Building average consumption: $120 \mathrm{~kW}$ per day $=43800$ KWh annually

Maximum power needed: $120 * 1.3=156 \mathrm{kWh}$ per day $=$ $56940 \mathrm{KWh}$ annually

Solar panels power: Needed energy to be generated / solar radiation rate

$56940 / 3084=18.5 \mathrm{KWh}$.

- Power of the monocrystalline solar panel $=1 \mathrm{KWh}$

- Number of needed panels: Power of panels needed / Power $18.5 / 1=19$ panel needed.

\section{b. Panels basic data:}

- The panels' orientation: panels will be installed facing the south direction based on the solar data analysis provided previously.

- The panels' inclination angle: will be $8^{\circ}$ in the summer, 46

${ }^{\circ}$ in the winter, and the best angle all over the year is $27^{\circ}$.

- The type of panels will be monocrystalline because it will give the best appearance and help in the design phase.

- The spacing between panels to avoid surplus shading of the panels on each other was calculated:

$$
\begin{gathered}
\mathrm{L} 1=2.7 \mathrm{~m}, \mathrm{~L} 2=3.97 \mathrm{~m}, \mathrm{~L} 3=6.67 \mathrm{~m}, \mathrm{H}=1.3 \mathrm{~m}, \mathrm{X}=3 \mathrm{~m}, \\
\mathrm{a}=18.4^{\circ}
\end{gathered}
$$

Fig (8),[16]

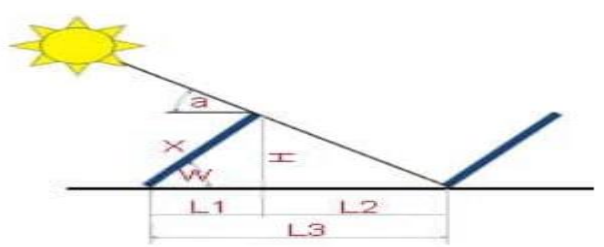

Fig .8 the spacing between panels

Ref: Nasr solar company for solar system. (2019), from, https://nasrsolar.com/, 8/2019.

After deciding the tilting angle, the orientation and the panel type comes the panel design phase on the roof of the building, and after the research, we will use a micro-inverter behind the panels (it has a small size)[15], and the panels are 
A: 102 MADIHA HAMED ABD ELSATTAR AMASHA, MOHAMED SALAH EL DIN EL SAYED, ALAA MOHAMED EL EISHY AND AHMAD EL TANTAWY AWAD

of different sizes, as the board consists of a group of PV cells connected in one frame and connected between them.

Cells are standard $15.6 \times 15.6 \mathrm{~cm}$

The 255-285-watt panels contain 60 cells $(6 * 10)$ and the size is $99 * 164 \mathrm{~cm}$

The 315-335-watt panels contain 72 cells $(6 * 12)$ and the size is $99 * 196 \mathrm{~cm} \mathrm{[17]}$

The 72-cell panels size $99 \times 196 \mathrm{~cm}$ were selected

so, the solar panel grid will be designed in 2 rows in parallel, each row equipped with 30 PV Panels, each panel contains 72 cells $(99 \times 196 \mathrm{~cm})$ with an electric output equal to 335.3 watts.

The basic study was designed with 19 PV Panels with an electric output equals to $1 \mathrm{KW}$ per panel; practically it is replaced by 3 PV Panels with an electric output equal to 335.3 watts per panel as mentioned above.

Fig (9) shows the proposed panel distribution including the maximum number of panels that could be installed.

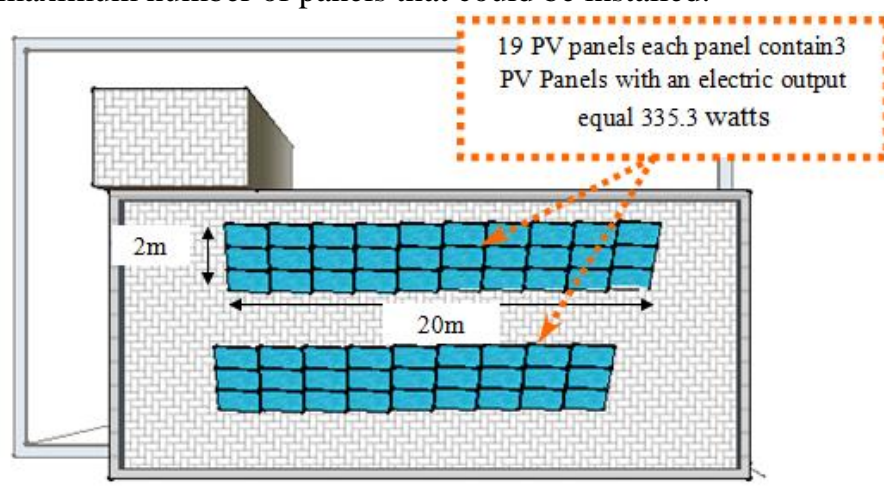

Fig.9 shows the proposed panel distribution in layot. By researcher

When we enter the building data in ZERO CODE the results in Zero code are almost like the results already obtained from Zero Tool, as well as annual AC\&DC production results.

In Zero code total energy consumption $=31.4$ $\mathrm{KWh} / \mathrm{m} 2 / \mathrm{yr}$

In Zero Tool EUI $=32 \mathrm{KWh} / \mathrm{m} 2 / \mathrm{yr}$

\section{H. Industrial zone as a Case Study:}

so we consider the industrial building model applicable to ZCA and apply it to the industrial zone as a whole to highlight the results economically and environmentally and optimize the benefit from it at the state level and generalize it in the industrial zone, in particular, to reduce economic burdens and support the state budget as well as to reduce pollution and CO2 emission.

Therefore, the above results will be applied to the industrial zone in the new city of Damietta as a case study, which contains approximately 75 industrial buildings.

By relating to long-term industrial development to produce the best outcomes by using a sustainable feasibility study to provide the country with positive returns for three axes:
a) Economically
b) environmentally
c) "Visually" in urban areas

\section{a) Economically:}

For one industrial building (case study), the target was set to be a $20 \%$ reduction in the use of energy while the building scores more than $\mathbf{8 1 \%}$ reduction.

The results saved 127 \{159-32\} KWh/m2/yr; in Site EUI.

For case study: we can save $\{127 * 1395 \mathrm{~m} 2\}=\mathbf{1 7 7 1 6 5}$

\section{$\mathrm{KWh} / \mathbf{y r}$}

This saved energy is estimated according to the energy prices in Egypt in 2020 for factories with heavy use (fifth tranche)

\section{$1.6 \mathrm{LE}$ for $1 \mathrm{KWh}$.}

\section{For all zone $\{177165 * 75$ buildings $\}$ almost produce $13287375 \mathrm{KWh} / \mathrm{yr}$}

\section{All zone can save about $\{283464 * 75$ buildings $\}=$ $21,259,800 \mathrm{LE}$ in the year.}

So, the one industrial building can save $\left\{1.6 \mathrm{LE}^{*} 177165\right\}$ $=283464 \mathrm{LE}$ in the year

In addition to the reduction of energy consumption (Research problem) at the level of the country, there are more than 21 million pounds, it can be saved for the state and used for several works, including:

- Maintenance of facilities, roads, etc.

- Create roads, sidewalks and, the lighting of roads; improve services and the work of advertising, etc.

- Double the profit and production in the long run at the level of factories.

\section{b) Environmentally:}

For one industrial building (case study),

From previous results, it saves 52 (76-24) metric tons $\mathrm{CO} 2 \mathrm{e} / \mathrm{yr}$; from total GHG emissions.

$$
\begin{gathered}
\text { For all zone it saves about }\{52 * 75 \text { buildings }\}=3900 \\
\text { metric tons } C O 2 e / y r
\end{gathered}
$$

So, this output will directly help reduce carbon emissions by almost $30 \%$ and thus reduce temperatures that contribute to the problem of global warming (Research problem).

\section{c) Urban "Visually":}

The level of urban and visually will contribute significantly to change the mental image of buildings by adding solar panels on the roof of the building or facade of the building as well as possible to create lighting poles solar energy to save more energy than to produce Zero Carbon City in the future.

\section{A OUESTIONNAIRE}

$\checkmark$ The questionnaire, was not relied upon, but it was presented as an appendix to confirm the results by asking specialists in architecture, environment, and energy

$\checkmark$-The questionnaire tool was selected as an important means of collecting information. Hence; we are looking forward 
to the results of the questionnaire as a credible indicator to answer the research questions and to confirm the results of the research and place it as a confirmed annex to the results

$\checkmark$ To respond to the research requirements, we have worked to understand the present and predicting the future in Egypt to set standards and scenarios for the future considering the indicators of the results of the questionnaire

\section{A. Objectives of the questionnaire}

a) Know the importance of using the principal of ZCA in Egypt "ZCAE" to influence architecture and the architect thinking in the design of buildings.

b) Identify the suitable sector in the buildings to implement ZCA standards to reduce carbon emissions and reduce energy consumption or to modify the buildings of whichever facility as determined by the results of the questionnaire.

c) Add criteria derived from the opinions and comments of the research sample within the framework of access to integrated standards to get to ZCAE.

d) Measuring the degree of interaction and partnership of decision-makers and financiers in future projects.

\section{B. Selection of research sample categories}

The questionnaire included 50 specialists in architecture and energy as follows:

- Researchers in the field of architecture and different specialties (architectural design, urban design)

- Researchers in the field of Environment.

- Specialists in project operation and financial issues.

- Researchers in the Architectural Formation

- decision-makers

\section{The results of the questionnaire}

a) ZCA application in Egypt has a strong effect on architecture and energy.

b) ZCAE application has a high cost.

c) ZCAE application is inexpensive in the long run.

d) Some curriculums should be developed to teach students of architecture applying the principles of ZCA.

e) A system must be formed to manage and activate ZCA in partnership with state institutions and major powers.

f) According to the activation of (ZCAE), formation elements must be modified.

g) ZCA application will create new quality architecture in the future and the mental image of the city will be changed.

h) ZCAE applied in new buildings at first

i) Starting to apply ZCAE in industrial buildings sector then residential buildings followed by educational and administrative buildings.

j) To apply ZCAE, designers and architects must be defined and trained in the principles of ZCA through workshops, training courses, explanatory seminars, scientific conferences.

The specialists also added:-
$\checkmark$-Training missions, development of university architectural education and Post University education.

$\checkmark$ Obtaining certificates in ZCA.

$\checkmark$ Field visits to examples of buildings applied and spreading awareness of the results.

$\checkmark$ Application of a system for the development and repairing of technical specifications of buildings by the principles of ZCA.

k) Application of the ZCA has environmental feasibility followed by economic feasibility.

1) Setting up an administrative apparatus to manage and active ZCAE its specialties are:

$\checkmark$ Activating ZCA as a part of the acceptance of the license of the buildings.

$\checkmark$ Management, follow-up, and development to reform the specifications of buildings and projects and spread awareness of the concept ZCA.

$\checkmark$ Developing legislation, monitoring implementation, and evaluation.

$\checkmark$ Support and supervision.

$\checkmark$ Coordination between this device and other state agencies specialized in construction and energy.

$\checkmark$-Environmental protection and management of natural resources.

$\checkmark$ The development of contemporary applications to adapt to the nature of the Egyptian environment.

m) To activate ZCA in Egypt, the following should be taken:

$\checkmark$ Spread awareness of the importance of ZCA application at all levels and spreading awareness and community culture.

$\checkmark$ Activate the environmental requirements of the building and apply the principles of sustainable design.

$\checkmark$ Link building licenses to an appropriate level of environmental performance.

$\checkmark$ Experimental application on some buildings and inventory and analysis of results.

$\checkmark$ The state and the society, especially the major institutions of adopted this thought.

$\checkmark$ Encourage partnership with the private sector as well as projects which applied ZCA.

$\checkmark$ Take advantage of global experiences in this field.

$\checkmark$ Provide specialized research laboratories to study the environment to produce architectural solutions.

$\checkmark$ Coordination with other organizations to activate ZCA.

$\checkmark$ Trying to coordinate between the principles of ZCA and the element of Egyptian architecture to reach a satisfactory degree of success.

\section{CONCLUSION}

a) In the Government's strategy to combat emissions particularly under the emissions trafficking scheme, the building sector might play a major role in reducing the cost of economic reduction across the country.

b) Technologies for low carbon include energy and design; these technologies considering the reduction of consumption of non-renewable energy and replace it with renewable energy. 
c) Low and zero-carbon technologies; However, the requisite low-carbon skills are trained in energy efficiency, comfort and thermal performance through engineering, and are produced to absorb information on window design, shading, and space design through professional practice

d) Zero carbon architecture (ZCA) aims to increase energy efficiency and enhance smart building technology.

e) By analysis of ZCA applications:

- In energy application:

i. Energy-saving technologies allow us to move into new high value-added areas both by creating new architecture and by radically changing traditional ones

- In the design application:

ii. Zero and Low Carbon Buildings can make a change in Working Practices by Use of Computer Modeling and Visualization to reduce the carbon emissions related to the built environment.

f) Zero carbon building achieves zero net carbon emissions through maximizing energy efficiency, comprehensive architectural design, resource recycling, and green land.

g) The most important interventions required to obtain ZCA were as follows:

Using renewable alternative energies such as solar energy

The use of smart materials such as nanomaterials,

especially in the building envelope

The use of modern, low-carbon technologies as in smart buildings

h) So, conclusions of the Applied study as follows:

Measuring ZCAE by using the international application

Zero Tool, the energy intensity use performance of the industrial building will be documented, and the amount of energy that needs to be generated from the building will be calculated.

This scenario will lead to a zero-carbon prototype in Egypt, with Utilize in the energy saving for the country at the urban, architectural, economic , and environmental levels as a scientific addition, as well as the possibility of a sustainable feasibility study of ZCAE as a future thought.

\section{Thus, the research reached results consistent with:}

- ZCA contributes to solving global warming, in the long run; it has a strong effect on architecture and energy, some curriculums should be developed.

- A system must be formed to manage and activate, ZCA in partnership with state institutions and major powers.

- ZCA application will create new quality architecture in the future.

- ZCAE applied in new buildings at first in the industrial buildings sector.

- To apply ZCAE, designers and architects must be defined and trained the principles of ZCA through workshops, training courses, explanatory seminars, scientific conferences.

- Application of the ZCA has environmental feasibility followed by economic feasibility.
- Spread awareness of the importance of ZCA application at all levels and spreading awareness and community culture.

And the results of the questionnaire confirmed that.

\section{RECOMMENDATIONS:}

Considering the above results, the research suggests the following recommendations:

a. Activate the framework of the applied study conducted by the research to include all buildings, to create a database through a specialized committee, and work on its application.

b. Develop some educational curricula such as architectural design to accommodate ZCA and its principles.

c. The need for the state to encourage and sponsor scientific research for this type of research and to hold training courses for all engineers working in this field.

d. After limiting the current situation to the state plan, we study industrial and logistics facilities and apply scenarios for the future and follow up.

e. Try to take advantage of global experiences and the application locally to new buildings and developing them to reduce energy consumption.

f. The importance of law-making and adoption using studies and future scenarios.

g. Develop existing projects for ZCA application to have economic, practical and environmental returns.

h. Technologies are at various stages of development, and so solutions must focus on both near-term commercialization for those technologies near the market and research, development, and demonstration for those further away.

i. Demanding the Egyptian companies producing different systems to support and finance research related to the systems of (PV).

j. Supporting and implementing ZCA thinking in all establishments that will be licensed or supervised.

\section{REFERENCES}

[1]The National Institute of Building Sciences, (2015), "A Common Definition for Zero Energy Buildings", U.S. Department of Energy 13,14. Retrieved 5 November 2020.

[2] Abbas Mansoury, Vahid Sattari-Naeini, Omid Abedi (Apr 2019), An Aging-aware Energy-efficient Data Collection Approach in Wireless Sensor Networks using Multiple Mobile Sinks, 2019 27th Iranian Conference on Electrical Engineering (ICEE).

[3]Eisenmann, Thomas R. "Managing Proprietary and Shared Platforms." California Management Review 50, no. 4 (Summer 2008)

[4] European Commission, ICT for a Low Carbon Economy Smart Buildings, Brussels, july2009, p18,19,20,21

[5]Hetherington, Robina; Laney, Robin and Peake, Stephen (2010). Zero and low carbon buildings: A driver for change in working practices and the use of computer modelling and visualization. In: 14th International Conference on Information Visualisation, 27-29 July 2010, London South Bank University, London, UK. p2

[6]Jan Allen. "The House that Green Built." New York Times. 20 April 2008. Last retrieved: 15 December 2013.

[7] New building institute, Five Steps to Net Zero Energy, 2016 National Grid USA Service Company, p5.

[8]P. Torcellini, S. Pless, and M. Deru, $(2006,6)$ " Zero Energy Buildings: A Critical Look at the Definition," National Energy Renewable Laboratory (NREL),Conference Paper, California,p 4,5 
[9]Poslad, Stefan (2009). Ubiquitous Computing Smart Devices, Smart Environments and Smart Interaction. Wiley. ISBN 978-0-470-03560-3. Archived from the original on 2014-12-10

[10] Stivers, T., Sidnell, J. Introduction: Multimodal interaction. Semiotica, 156(1/4), pp. 1-20. 2005 Web links:

[11] US Environmental Protection Agency, "Green Building," 16 Apr.2008 https://archive.epa.gov/greenbuilding/web/html, 2020.

[12] architecture2030. (2019) from architecture2030, https://architecture2030.org/advancing-net-zero-worldwide/7/2019.

[13] Ashrae. organization, (2020), from, ashrae.org/about/news/2015/defining-zero-energy-and-the-pathway-toachieving-it-explored-at-ashrae-conference $11 / 20$

[14] cagbc.organization(2017),from,cagbc.org/cagbcdocs/zerocarbon/CaGB C_Zero_Carbon_Building_Standard_EN.pdf Canada Green Building Council, May 2017

[15] Ashrae. organization (2019), from, ashrae.org en-us/products-andservices/microinverters, 2019

[16] Nasr solar company for solar system. (2019), from, https://nasrsolar.com/, 8/2019.

[17] PV education organization. (2019), from, https://www.pveducation.org/pvcdrom/modules-and-arrays/modulecircuit-design, 2019.

[18] Resources. News, (2020), from, resources.news.e.abb.com/attachments/published/41199/enUS/A636170 BDC32/Ludenscheid_Mission_to_Zero.PNG, 10/20

[19] Zero tool organization. (2019) from zerotool.org, https://zerotool.org/about/\#toggle-id-6, 8/2019
Title Arabic:

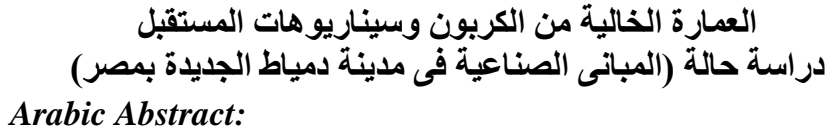

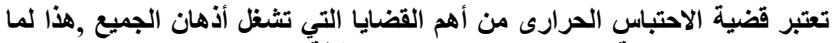

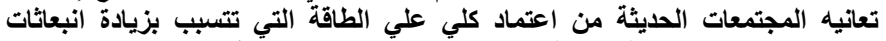

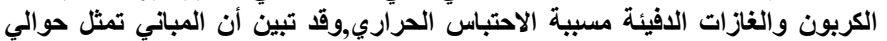

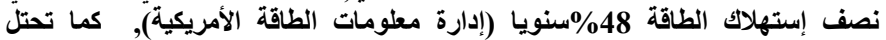

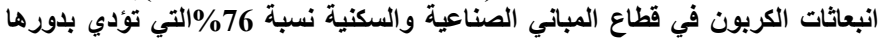

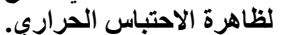

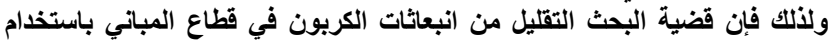

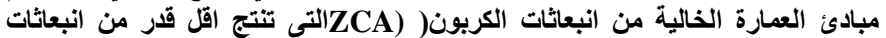

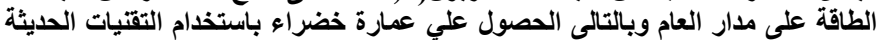
واستخدام الطاقة البديلة لتقليل استهلاك الطول الطاقة.

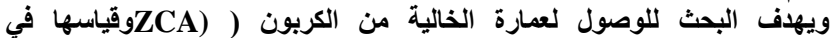

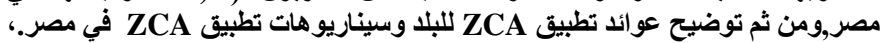

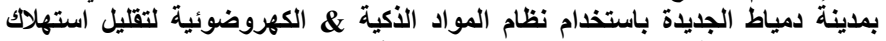

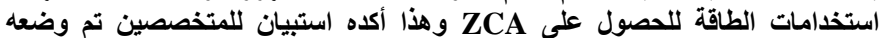

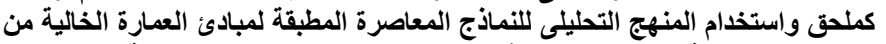

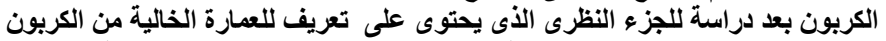

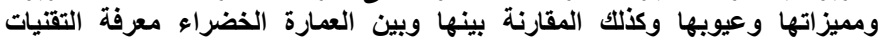

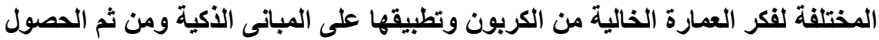

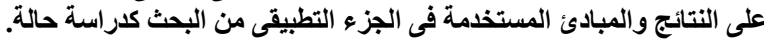

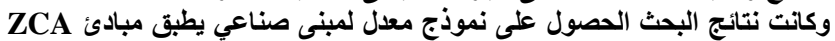

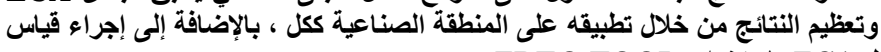

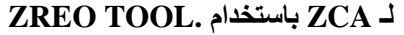

